\title{
P58. Can T-cells predict response to intravesical BCG immunotherapy in high-risk non-invasive bladder cancer
}

\author{
S Jallad ${ }^{1 *}$, P Thomas', M Newport ${ }^{2}$, F Kern $^{2}$ \\ From 1st Immunotherapy of Cancer Conference (ITOC1) \\ Munich, Germany. 12-14 March 2014
}

\section{Introduction}

Intravesical BCG is an example of the importance of immunotherapy in cancer treatment. It has been used since the 1970s as it has a major impact in preventing or delaying bladder cancer recurrence and possibly progression. Unfortunately $20-30 \%$ of patients who receive this treatment do not respond and they are at high risk of dying from their disease. Being able to predict response to treatment would be an invaluable tool in those patients and would help in directing them to the appropriate treatment modalities. We investigated whether immunological markers in blood can predict outcome.

\section{Methods}

Patients with high risk non-invasive bladder cancer and due to have BCG immunotherapy were included. Blood samples were obtained before and after BCG-induction treatment. In vitro stimulation of peripheral-blood mononuclear cells with PPD which were then labelled with extra and intracellular markers in order to assess the differentiation and activation status of T-cells.

\section{Results}

13 patients had no recurrence on follow-up cystoscopy while 6 had persistent disease. Differences were seen between the two groups in mean percentage of Interferon gamma positive (INF $\gamma+$ ) CD4 in response to PPD stimulation; $1.84 \%( \pm 1.58)$ in the recurrence-free group versus $0.54 \%( \pm 0.72)$ in the recurrence group [ $P$ value 0.0252 ] This was more clear in the specialised subset [CCR7CD27-CD28+]; 2.46\% $( \pm 1.96)$ and $0.77 \%( \pm 0.80)$ respectively [ $P$ value 0.0168$]$. And in the [CCR7-CD27-CD28+]

${ }^{1}$ Royal Sussex County Hospital, Urology, Brighton, UK

Full list of author information is available at the end of the article subset; $5.07 \%( \pm 4.19)$ and $1.12 \%( \pm 1.25)$ respectively $[P$ Value 0.0067]. The mean percentages of pre-treatment tumour necrosis factor positive (TNF+) cells were also significantly different in the [CCR7-CD27-CD28+] subset; $8.82 \%( \pm 6.06)$ and $3.10 \%( \pm 3.81)$ respectively $[P$ value $0.0246]$.

\section{Conclusion}

In bladder cancer immunotherapy, the percentage of PPD inducible INF $\gamma+$ and TNF+ CD4 cells can potentially predict outcome to treatment.

\section{Authors' details}

${ }^{1}$ Royal Sussex County Hospital, Urology, Brighton, UK. ${ }^{2}$ Brighton and Sussex Medical School, Urology, Brighton, UK.

Published: 12 March 2014

doi:10.1186/2051-1426-2-S2-P32

Cite this article as: Jallad et al:: P58. Can T-cells predict response to intravesical BCG immunotherapy in high-risk non-invasive bladder cancer. Journal for ImmunoTherapy of Cancer 2014 2(Suppl 2):P32.

Submit your next manuscript to BioMed Central and take full advantage of:

- Convenient online submission

- Thorough peer review

- No space constraints or color figure charges

- Immediate publication on acceptance

- Inclusion in PubMed, CAS, Scopus and Google Scholar

- Research which is freely available for redistribution

Submit your manuscript at www.biomedcentral.com/submit 